\title{
Designing a Radioimmunometric Hssay Kit for Prostate-Specific Antigen Measurement Using Polystyrene Tubes Coated By Immunochemical Method
}

\author{
Haleh Foroutan (MSc) \\ Faculty member, Radiation \\ Applications Research School, \\ Nuclear Science and Technology \\ Research Institute, Atomic Energy \\ Organization of Iran, Tehran, Iran
}

Marziyeh Khodabakhsh (MSc) Radiation Applications Research School, Nuclear Science and Technology Research Institute, Atomic Energy Organization of Iran, Tehran, Iran

Masoud Moharamzadeh (MSc) Radiation Applications Research School, Nuclear Science and Technology Research Institute, Atomic Energy Organization of Iran, Tehran, Iran

Corresponding author: Haleh Foroutan

Email: hforoutan@aeoi.org.ir Tel: +982182062803

Address: Radiation Applications Research School, Nuclear Science and Technology Research Institute, Atomic Energy Organization of Iran, Karegar

Avenue, Tehran, Iran

Postal code: 11365-3486

\begin{abstract}
Background and Objective: Prostate specific antigen (PSA) is considered as one of the most reliable biomarkers of cancer and other known prostate diseases. In the present study, solid phase sandwich immunoradiometric assay was used to measure the amount of PSA. In this type of measurement, a pair of anti-PSA antibodies on the solid phase and labeled with Iodine-125, participate in forming a complex with two different epitopes of PSA.

Methods: Variables such as irradiation level, modification of polymer surfaces by alcohol washing, different concentrations and volumes of antibody, incubation temperature and drying conditions that influence the direct coating process were optimized. Finally, the stability, accuracy and precision of the laboratory kit were evaluated by comparison with a foreign kit.

Results: According to the obtained results, preliminary preparations such as irradiation, tube washing and specific temperature conditions are not required during the coating process. Drying by lyophilization method does not affect the quality of coating. Antibody concentration of $2.5 \mu \mathrm{g} / \mathrm{ml}$ and coating volume of $800 \mu$ were determined as the optimum conditions for coating, which had good stability within a year. Alignment of results obtained from the domestic and foreign kits for accuracy of 30 samples from patients was confirmed by T-test (sig 2-tailed $=0.993$ and $95 \%$ confidence interval). The short-term and long-term precision for three control ranges (low, medium, high) were less than 0.25 and 0.33 of allowable total error $(\mathrm{TEa}=10 \%)$, respectively.

Conclusion: The produced domestic kit has acceptable precision according to the CLIA criteria.
\end{abstract}

Keywords: Biological testing, Radioimmunometric assay, monoclonal antibody, prostate specific antigen, prostate disease.

Received : 10 Aug 2014

Revised: 01 Feb 2015

Accepted: 02 Feb 2015 


\section{INTRODUCTION}

Prostate cancer is the sixth most common cancer in the world and the third most common type of cancer in men. Therefore, early diagnosis prior to progression and metastasis to other parts of the body is of great importance for prevention and patients' follow-up. Prostate-specific antigen (PSA) is a 26-33 kDa single-chain glycoprotein and serine protease belonging to kallikrein family, which is secreted by the prostate (1). In blood, PSA molecule is either in free form or bound to serum protein, mainly to $\alpha-1$ antichymotrypsin. The ratio of these two forms varies depending on the type of disease, and is a good indicator of the type of prostate disease $(2,3)$. Thus , the amount of this antigen is measured as an effective marker in prostate disease screening tests and for timely diagnosis of prostate diseases. The PSA measurement prior to digital rectal examination can be also effective (4-6). The PSA level is measured as a tumor marker in immunological methods using monoclonal antibodies. These methods can detect the marker based on physical and biological features of the antigen-antibody complex $(7,8)$. The Sandwich immunoradiometric assay was used in this study to measure PSA levels. In this type of measurement, a pair of anti-PSA specific antibodies on the solid phase and labeled with Iodine-125, participate with two different epitopes of PSA in forming a complex (9). Monoclonal antibody-coated solid phase is a key component of the immuneradiometric methods. Polymer beads, latex particles and polymer tubes are used as solid phase systems for coating with antibodies. The Iranian polystyrene polymer tubes were used in this study, due to simplicity in testing and low nonspecific binding levels (10). The polymer tubes are coated either directly (passive) or indirectly (active) (11-12). In the indirect method, surface of the polymer is coated with another protein to increase the active site on the surface of the polymer and enhance the binding capacity of antibody. In spite of being specific, this method requires preliminary preparation. It is also limited because of the possibility of interference with other proteins, lengthy process and cost of production. The factors such as quality of tubes, antibody's purity, coating method, $\mathrm{pH}$ of buffers used, storage temperature, and drying method affect the stability and quality of coated tubes. In this study, the direct method of coating was done on Iranian polystyrene tubes for preparation of the immunoradiometric assay (IRMA) kit, because of its simplicity, low-cost and shortened production process. Optimization of tubes' coating conditions, its application in the IRMA kit and finally the results of quality control using real samples and control serums for PSA analysis are discussed and compared with a valid foreign kit (Immunotech) with tubes coated via the indirect method and according to Clinical Laboratory Improvement Amendments (CLIA) criteria (13).

\section{MATERIAL AND METHODS}

Gamma counter (GammaTech co., model 600 B), fraction collector (Pharmacia Biotech), peristaltic pumps (Pharmacia LKB pump), Anti-PSA specific monoclonal antibody for coating $(1.05 \mathrm{mg} / \mathrm{ml}$, Medix Biochemica Co.) and Iranian polystyrene tubes (Kariz Mehr Co.) were purchased. Standard PSA concentrations $(0,1,3,10,30,100 \mathrm{ng} / \mathrm{ml})$, control serum (prepared at the nuclear biomolecule laboratory) and a pair of monoclonal antibodies labeled with iodine-125 (prepared at the labeling laboratory of Nuclear Science and Technology Research Institute) were used. The serum samples were obtained from male volunteers working in the laboratory of Yousef Abad and the Nuclear Science and Technology Research Institute. Sodium dihydrogen phosphate, disodium hydrogen phosphate, sodium azide, and Tris were purchased from Merck Co. Citric acid, sodium citrate, bovine serum albumin (BSA), sucrose, sodium azide, and Triton X100 were purchased from Sigma Co.

1. Direct coating of Iranian polystyrene tubes Anti-PSA monoclonal antibody for coating with three specific concentrations $(1,2.5,5$ $\mu \mathrm{g} / \mathrm{ml})$ was prepared in coating buffer $[(0.1 \mathrm{M}$ phosphate buffer containing $0.5 \%$ sodium azide $(\mathrm{pH}=7.4)]$. Then, sufficient amounts of the antibody were added to the polystyrene tubes. After being at room temperature for 24 hours, the tubes were emptied and replaced with blocking buffer $[0.05 \mathrm{M}$ tris, $0.02 \mathrm{M}$ citric acid, $0.04 \mathrm{M}$ sodium citrate, $1 \%$ BSA, $1 \%$ sucrose and $0.1 \%$ sodium azide $(\mathrm{pH}=7.4)$ ]. The tubes were placed at room temperature for 24 hours. The tubes were emptied and kept in a refrigerator for necessary testing. 
2. Analysis of IRMA kit for measurement of total PSA concentration A certain amount of sample (blood serum of males or control serum) or standards (prepared in the laboratory with concentrations of $0,1,3,10,30,100 \mathrm{ng} / \mathrm{ml}$ ) with an appropriate volume of the labeled antibody [(a pair of monoclonal antibodies labeled with iodine-125 using the chloramine$\mathrm{T}$ method (4)] were exposed to each other in the coated tubes for 2 hours. The tube were emptied and washed twice with $2 \mathrm{ml}$ of washing solution (containing $0.1 \%$ Triton $\mathrm{X} 100$ ), to remove debris and unabsorbed substances. The level of binding radioactivity was measured by the Gamma counter. Total PSA concentration in the sample is directly correlated with the amount of radioactivity. It should be noted that the control samples $(\mathrm{C} 1$, $\mathrm{C} 2$ ), standards and antibodies labeled with iodine-125 were prepared in the laboratory. The range of serum concentration of controls and standards was determined and controlled by the foreign kit.

3. Investigation of factors affecting the coating Before coating, the amount of irradiation and alcohol-washing conditions were investigated for preliminary preparation. Different concentrations and volumes of the antibody were used for coating the tubes. The calibration curve was plotted using the standards, and the control samples were analyzed by comparison with the foreign kit (Immunotech). The incubation temperature was $25^{\circ} \mathrm{C}$. After coating at optimal conditions, the tubes were dried using a vacuum drying system and lyophilization. After optimization of conditions, the stability, accuracy and precision of the kit were evaluated. All experiments were done in triplicate.

\section{RESULTS} coating

1. Investigation of factors affecting the

1.1 Effect of irradiation on tubes' coatings

Before coating and for preliminary preparation, different doses of gamma-ray (10, 25 and $50 \mathrm{kGy}$ ) were irradiated. Then, coating was done using the direct method $(5 \mu \mathrm{g} / \mathrm{ml}$ of antibody with coating volume of $800 \mu \mathrm{l}$ per tube). The results of tubes' analysis show that irradiation does not affect the results of the analysis (Table 1).
1.2 Effect of temperature and washing the tubes with alcohol Before coating and for preliminary preparation, the tubes were washed with alcohol and then coated with 5 $\mu \mathrm{g} / \mathrm{ml}$ antibody and $800 \mu \mathrm{l}$ of coating buffer with different temperature conditions (room temperature and incubation at $25^{\circ} \mathrm{C}$ ). It seems that incubation and washing with alcohol did not affect the coating process compared to normal conditions (room temperature, without washing) (Table 2).

1.3 Effect of antibody's concentration and coating volume

Different concentrations and volumes of the antibody were used for coating the tubes (20 repetitions). The calibration curve was plotted using the standards of the foreign kit and the standards prepared at the laboratory, and the concentration of control samples were analyzed. The calibration curve for the domestic kit with optimal concentration and volume of antibody was compared using the foreign and domestic kits' standards (Figure 1). To evaluate the accuracy of the data, the concentration of control samples was determined by the foreign kit (three repetitions). The calibration curve was plotted for each time of coating, and the concentration of controls was analyzed using the coated tubes (three repetitions). The average of results at different conditions was compared with the foreign kit [coefficient of variation (CV) $<6 \%$ ](Figures 2 and 3). Based on the proper calibration curve (without Hook effect), low non-specific binding (less than 200 count/min) and comparison of $\mathrm{C} 1$ and $\mathrm{C} 2$ concentrations' analysis using the domestic and foreign kits, $2.5 \mu \mathrm{g} / \mathrm{ml}$ of antibody and volume of $800 \mu \mathrm{l}$ were found as the optimal conditions for coating. Stability of the coated tubes and quality control of the kit were investigated.

1.4 Effect of drying system for coated tubes After passive coating at optimal conditions, the tubes were vacuum dried (30 minutes) and lyophilized (overnight). Comparison of mean concentrations of $\mathrm{C} 1$ and $\mathrm{C} 2$ shows that lyophilization did not affect the coating quality. However, the concentration of $\mathrm{C} 2$ obtained under vacuum drying was less than acceptable range. The stability of the kit prepared using lyophilization will be discussed in the next section. 
Table 1- Effect of irradiation on the analysis of coated tubes

\begin{tabular}{cccc}
\hline Dose $(\mathrm{kGy})$ & $\begin{array}{c}\text { Percentage of maximum } \\
\text { binding/total count ratio }\end{array}$ & $\begin{array}{c}\text { Concentration of sample C1 } \\
(\mathrm{ng} / \mathrm{ml})\end{array}$ & $\begin{array}{c}\text { Concentration of sample C2 } \\
(\mathrm{ng} / \mathrm{ml})\end{array}$ \\
\hline $\mathbf{0}$ & $\mathbf{3 9}$ & $\mathbf{5 . 5 8}$ & 17.09 \\
$\mathbf{1 0}$ & $\mathbf{3 2}$ & $\mathbf{5 . 5 2}$ & 16.89 \\
$\mathbf{2 5}$ & $\mathbf{3 1}$ & $\mathbf{5 . 5 0}$ & 15.10 \\
$\mathbf{5 0}$ & $\mathbf{3 4}$ & $\mathbf{5 . 5 0}$ & 16.15 \\
\hline
\end{tabular}

Table 2- Effect of temperature and alcohol washing on the coating process

\begin{tabular}{cccc}
\hline Coating conditions & $\begin{array}{c}\text { Percentage of maximum } \\
\text { binding/total count ratio }\end{array}$ & $\begin{array}{c}\text { Concentration of sample C1 } \\
(\mathrm{ng} / \mathrm{ml})\end{array}$ & $\begin{array}{c}\text { Concentration of sample C2 } \\
(\mathrm{ng} / \mathrm{ml})\end{array}$ \\
\hline $\begin{array}{c}\text { Alcohol washing and room } \\
\text { temperature }\end{array}$ & 20 & 5.0 & $\mathbf{2 4 . 5}$ \\
$\begin{array}{c}\text { Alcohol washing and } \mathbf{2 5} \\
{ }^{\circ} \mathbf{C}\end{array}$ & 19 & 4.9 & $\mathbf{2 3 . 6}$ \\
$\begin{array}{c}\text { No washing and room } \\
\text { temperature }\end{array}$ & 30 & 5.50 & $\mathbf{2 4 . 6}$ \\
No washing and $\mathbf{2 5}{ }^{\circ} \mathbf{C}$ & 26 & 4.50 & $\mathbf{2 0 . 5}$ \\
\hline
\end{tabular}

Figure 1- Comparison of the calibration curves of the immunometric kit for measurement of PSA using the domestic and foreign kits' standards

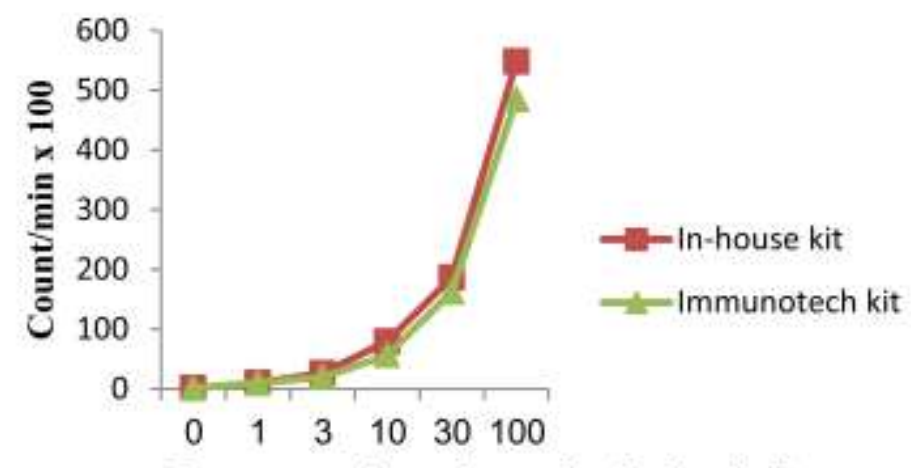

Concentration of standards $(\mathrm{ng} / \mathrm{ml})$

Figure 2- Comparison of $\mathrm{C} 1$ concentrations in the domestic kit and the foreign kit using different antibody concentrations $(1,2.5$ and $5 \mu \mathrm{g} / \mathrm{ml})$ and coating volumes $(400,800,1000 \mu \mathrm{g} / \mathrm{ml})$

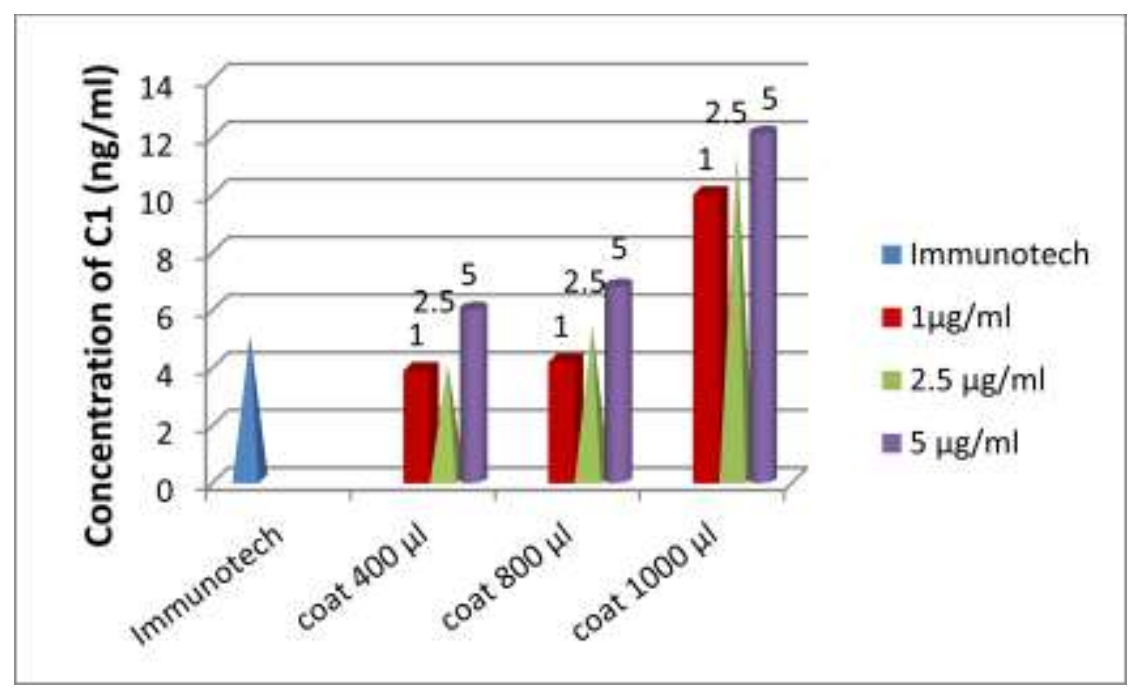


Figure 3- Comparison of $\mathrm{C} 2$ concentrations in the domestic kit and the foreign kit using different antibody concentrations $(1,2.5$ and $5 \mu \mathrm{g} / \mathrm{ml})$ and coating volumes $(400,800,1000 \mu \mathrm{g} / \mathrm{ml})$

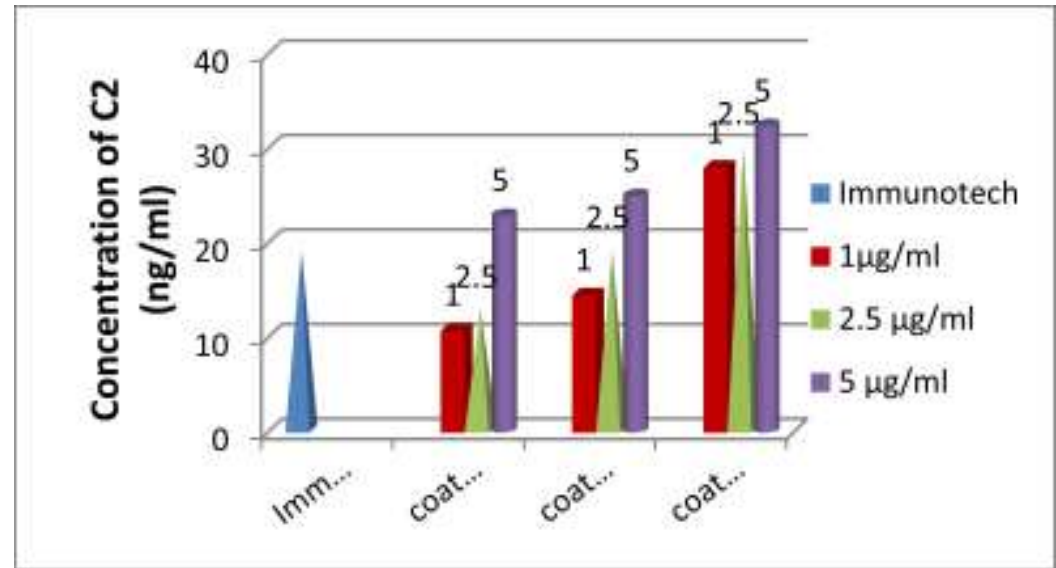

Table 3- Effect of drying condition on concentration of the control samples

\begin{tabular}{ccc}
\hline Drying condition & $\begin{array}{c}\text { Concentration of C2 } \\
(4-8 \mathrm{ng} / \mathrm{ml})\end{array}$ & $\begin{array}{c}\text { Concentration of C2 } \\
(18-27 \mathrm{ng} / \mathrm{ml})\end{array}$ \\
\hline Without drying & 5.3 & 19.2 \\
Vacuum drying & 5.5 & 14.5 \\
Lyophilization & 5.7 & 20.8 \\
\hline
\end{tabular}

Figure 4- Stability of the tubes over time

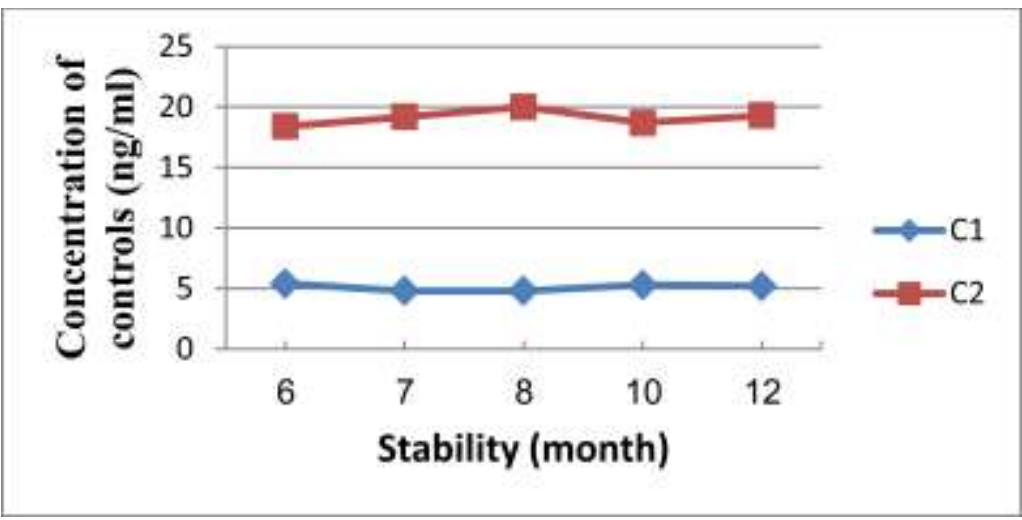

Figure 5- Comparison of linear regression analysis of real samples using the reference (comparative method) and domestic (test method) kits

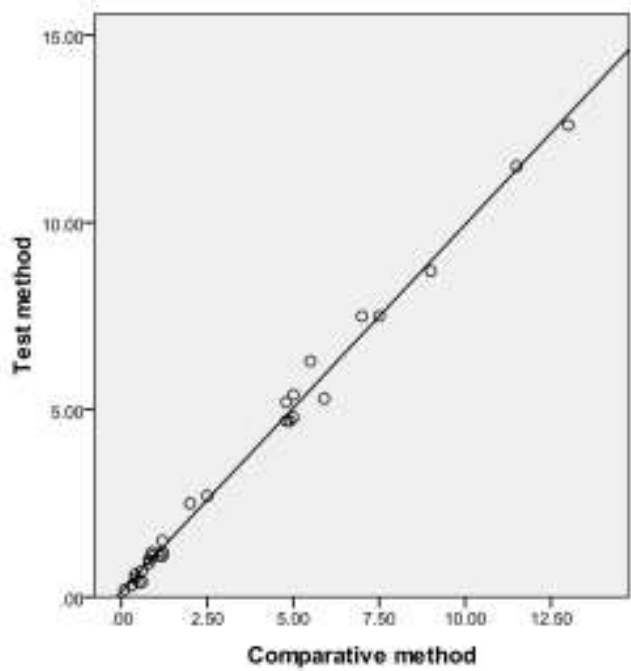

Lnear Pecression 
2. Stability of the coated tubes

In order to investigate the stability of coated tubes (at optimum conditions), the concentration of controls was measured at five different time intervals (Figure 4). The results show that the coated tubes had good stability for one year.

3. Quality control of IRMA kit containing coated tubes for analysis of total PSA concentration

3.1 Accuracy of the kit: In order to investigate the accuracy of the produced kit, 30 real samples were analyzed simultaneously using the foreign (Immunotech) and domestic kits. Linear regression analysis (Figure 5), T-test (to calculate components of regression), correlation coefficient $(\mathrm{R} 2=0.993)$, mean difference (bias $=0.1$ ) and total error (TEcal=1.6) were studied. Alignment of results of the two kits was investigated according to the results obtained from the Ttest.
Based on the paired independent t-Test (with equal variances in the results of the domestic and reference kits), Sig (2-tailed) 0.933 was achieved, which is much larger than 5\% (95\% confidence interval). Thus, the alignment of the results of both kits was confirmed.

3.2 The precision of the kit

In order to estimate the imprecision of the kit, test-retest reliability was analyzed for three control ranges [low (C1), medium (C2), high (C3)] with 20 repetitions in three runs. The means, standard deviation (SD) and CV (\%) were calculated (Table 4). The SD of less than 0.25 of the allowable total error $(\mathrm{TEa}=10 \%)$ was obtained within a run (Sw-run). The SD of less than 0.33 of the TEa was achieved for long-term imprecision of overall standard deviation (S total). Short-term and long-term imprecisions were calculated according to the CLIA criteria. The precision of the PSA diagnostic kit was acceptable.

Table 4- Precision of the total PSA diagnostic kit

\begin{tabular}{|c|c|c|c|c|c|c|c|c|c|}
\hline & \multicolumn{3}{|c|}{ C1(ng/ml) } & \multicolumn{3}{|c|}{$\mathrm{C2}(\mathrm{ng} / \mathrm{ml})$} & \multicolumn{3}{|c|}{$\mathrm{C3}(\mathrm{ng} / \mathrm{ml})$} \\
\hline & 1 & 2 & 3 & 1 & 2 & 3 & 1 & 2 & 3 \\
\hline Means ( 20 repeats) & 1.86 & 1.58 & 1.83 & 4.38 & 5.06 & 4.46 & 23.98 & 20.41 & 23.77 \\
\hline SDw-run* & 0.18 & 0.16 & 0.19 & 0.26 & 0.27 & 0.18 & 1.48 & 0.90 & 0.81 \\
\hline CV\% & 9.7 & 10 & 10.8 & 5.9 & 5.4 & 3.9 & 6.18 & 4.4 & 3.4 \\
\hline \multicolumn{10}{|l|}{ (Within a run) } \\
\hline Total mean & & 1.75 & & & 4.63 & & & 22.72 & \\
\hline SD- total* & & 0.15 & & & 0.37 & & & 2.0 & \\
\hline $\begin{array}{c}\text { Total CV\% } \\
\text { (Between runs) }\end{array}$ & & 8.7 & & & 7.9 & & & 8.8 & \\
\hline
\end{tabular}

\section{DISCUSSION}

Normally, proteins are irreversibly adsorbed onto polymer or plastic surfaces. Higher molecular weight of protein is accompanied with a stronger adsorption. Antibodies are a group of proteins (immunoglobulins) that well exhibit this property. The irreversible adsorption onto plastic surface is called the coating phase. The coated tubes are the polymer tubes that antibodies are absorbed onto their internal surfaces. The protein absorption onto polymer depends on electrical charge of the protein and their hydrophobic interactions. First, a monomolecular antibody is formed on the hydrophobic plastic surface. The nature of the binding mechanism is not clear, but the factors such as concentration, $\mathrm{pH}$, ionic strength, time, temperature and viscosity are effective on the properties of the coated surfaces. The proteins will have their best coating at a specific $\mathrm{pH}$ close to their isoelectric point. Molarity of buffer is another effective factor. Antibody absorption level is inversely correlated with the concentration of buffer's salts. The interaction conditions are optimized in the coating phases according to the kit's assessment criteria It is difficult to control the conditions in passive method of coating. Thus, covalent coupling between the protein and the plastic surface is recommended. In some cases, reactive groups such as carboxyl or amine are placed onto surfaces using chemical modification. However, the passive method of coating is practically easier and more cost-effective for manufacturers.

In this study, different conditions affecting the coating process were investigated to achieve coating technology for Iranian polymer tubes using a monoclonal antibody (passive method). Three specific concentrations of antiPSA monoclonal antibody were coated on polystyrene tubes. The influencing factors such as irradiation, washing, temperature, 
concentration and volume of the antibody were investigated. Each factor was compared within the desired range with regard to the kit's analysis. The results showed that the factors such as irradiation and washing do not affect the quality of suitable site for coating onto the tubes' polymer surface. However, the concentration and volume of the antibody affect the interaction between pair of antibodies. The impact of different concentrations and volumes of antibody for coating was analyzed by plotting calibration curve for concentrations of the control samples. Optimal coating conditions were determined with respect to the appropriate calibration curve (without Hook effect), low non-specific binding and comparison of control samples' concentration analysis. Then, the stability of coated tubes and quality control of the kit were evaluated. Two methods of vacuum drying and lyophilization were investigated for long-term storage of the coated tubes. Then, the stability and accuracy of the kit in each method were compared. Ttest was done on 30 real samples in order to assess the accuracy of the produced kit under optimal conditions. The alignment of the results of the domestic and foreign kits' accuracy was confirmed, which indicates lack of interference of the coated antibody with

\section{REFERENCES}

1. Shaw JE, Sicree RA, Zimmet PZ. Global estimates of the prevalence of diabetes for 2010 and 2030. Diabetes Res Clin Pract. 2010; 87(1): 4-14. doi: 10.1016/j.diabres.2009.10.007.

2. Esteghamati A, Gouya MM, Abbasi M, Delavari A, Alikhani S, Alaedini F, et al. Prevalence of diabetes and impaired fasting glucose in the adult population of Iran: National Survey of Risk Factors for NonCommunicable Diseases of Iran. Diabetes Care 2008; 31(1): 96-98.

3. Wright E Jr, Scism-Bacon JL, Glass LC. Oxidative stress in type 2 diabetes: the role of fasting and postprandial glycaemia. Int J Clin Pract. 2006; 60(3): 308-314. doi: 10.1111/j.1368-5031.2006.00825.x.

4. Farbstein D, Kozak-Blickstein A, Levy AP. Antioxidant Vitamins and Their Use in Preventing Cardiovascular Disease. Molecules. 2010; 15(11): 8098110. doi: 10.3390/molecules15118098.

5. Rodrigues E, Mariutti LR, Mercadante AZ. Scavenging capacity of marine carotenoids against reactive oxygen and nitrogen species in a membranemimicking system. Mar Drugs 2012; 10(8): 1784-1798.

6. Engin KN. Alpha-tocopherol: looking beyond an antioxidant. Molecular Vision 2009; 15:855-860. other blood serum components. Short-term precision of the kit was evaluated and SD $<0.25$ of the allowable total error $(\mathrm{TEa}=10 \%)$ was obtained within a run (Sw-run) for three control concentrations (low, medium, high). The long-term precision of the kit was also evaluated and $S$ total $<0.33$ of the allowable total error $(\mathrm{TEa}=10 \%)$ was obtained in three runs for three control concentrations (low, medium, high).

\section{CONCLUSION}

Considering the results obtained, the kit's quality control, calculated short-term and longterm imprecision according to accredited criteria of CLIA for diagnostic kits, the domestic kit produced without preliminary preparation has acceptable precision and suitable quality for measurement of PSA levels in serum.

\section{ACKNOWLEDGMENTS}

The authors wish to acknowledge gratefully the help and co-operation of all colleagues in the Nuclear Biomolecule Department of Radiation of Applications Research Institute for providing the facilities for this study.

\section{CONFLICT OF INTEREST}

We have no conflict of interest to declare.

7. Liu S, Lee IM, Song Y, Van Denburgh M, Cook NR, Manson JE, et al. Vitamin E and Risk of Type 2 Diabetes in the Women's Health Study Randomized Controlled Trial. Diabetes. 2006; 55(10): 2856-2862.

8. Murthy VK, Shipp JC, Hanson C, Shipp DM. Delayed onset and decreased incidence of diabetes in $B B$ rats fed free radical scavengers. Diabetes Res Clin Pract. 1992; 18(1): 11-16. doi:10.1016/0168-8227(92)90049-W.

9. Sargeant LA, Wareham NJ, Bingham S, Day NE, Luben RN, Oakes S, et al. Vitamin $C$ and hyperglycemia in the European Prospective Investigation into CancerNorfolk (EPIC-Norfolk) study: a population-based study. Diabetes Care 2000; 23(6): 726-732.

10. Shim JE, Paik HY, Shin CS, Park KS, Lee HK. Vitamin $C$ nutriture in newly diagnosed diabetes. $\mathrm{J}$ nutr SciVitaminol. 2010; 56(4): 217-221.

11. Wali U, Jogana MU, Zarummai AL, Saidu Y. Antioxidant Vitamins and Trace Elements Status of Diabetics in Sokoto, Nigeria. Nigerian Journal of Basic and Applied Science. 2011; 19(1): 130-134

12. Azar M, Basu A, Jenkines AJ, Nankervis AJ, Hanssen KF, Scholz H, et al. Serum Carotenoids and Fat-Soluble Vitamins in WomenWith Type 1 Diabetes and Preeclampsia. Diabetes Care 2011; 34(6): 1258-64. doi: $10.2337 / \mathrm{dc} 10-2145$. 
13. Polidori MC, Mecocci P, Stahl W, Parente B, Cecchetti R, Cherubini A, et al. Plasma levels of lipophilic antioxidants in very old patients with type 2 diabetes. Diabetes Metab Res Rev. 2000; 16(1): 15-19.

14. Feskens EJ, Virtanen SM, Räsänen L, Tuomilehto J, Stengård J, Pekkanen J, et al. Dietary factors determining diabetes and impaired glucose tolerance. A 20-year follow-up of the Finnish and Dutch cohorts of the Seven Countries Study. Diabetes Care. 1995; 18(8): 1104-1112.

15. Mullan BA, Young IS, Fee H, McCance DR. Ascorbic acid reduces blood pressure and arterial stiffness in type 2 diabetes. Hypertension 2002; 40(6): 804-809.

16. Paolisso G, Balbi V, Volpe C, Varricchio G, Gambardella A, Saccomanno F, et al. Metabolic benefits deriving from chronic vitamin $C$ supplementation in aged non-insulin dependent diabetics. J Am Coll Nutr 1995; 14(4): 387-392.

17. Regensteiner JG, Popylisen S, Bauer TA, Lindenfeld $\mathrm{J}$, Gill E, Smith S, et al. Oral L-arginine and vitamins $E$ and $C$ improve endothelial function in women with type 2 diabetes. Vasc Med. 2003; 8(3): 169-175.

18. Chen H, Karne RJ, Hall G, Campia U, Panza JA, Cannon RO 3rd, et al. High-dose oral vitamin C partially replenishes vitamin $\mathrm{C}$ levels in patients with Type 2 diabetes and low vitamin $\mathrm{C}$ levels but does not improve endothelial dysfunction or insulin resistance. Am J Physiol Heart Circ Physiol. 2006; 290(1): H137-145.

19. Darko D, Dornhorst A, Kelly FJ, Ritter JM, Chowienczyk PJ. Lack of effect of oral vitamin $\mathrm{C}$ on blood pressure, oxidative stress and endothelial function in Type II diabetes. Clin Sci. 2002; 103(4): 339-344.

20. Bishop N, Schorah CJ, Wales JK. The effect of vitamin $\mathrm{C}$ supplementation on diabetic hyperlipidaemia: a double blind, crossover study. Diabet Med. 1985; 2(2): 121-124.

21. Liu S, Lee IM, Song Y, Van Denburgh M, Cook NR, Manson JE, et al. Vitamin E and risk of type 2 diabetes in the women's health study ran domized controlled trial. Diabetes. 2006; 55(10): 2856-2862.

22. American Diabetes Association. Diagnosis and Classification of Diabetes Mellitus. Diabetes Care 2010; 33(Suppl 1): S62-S69. doi: 10.2337/dc10-S062.

23. Hrebicek J, Janout V, Malincikova J, Horakova D, Cizek L. Detection of insulin resistance by Simple quantitative insulin sensitivity checks index QUICKI for epidemiological assessment and prevention. J Clin Endocrinol Metab. 2002; 87(1): 144-147.

24. Eriksson J, Kohvakka A. Magnesium and ascorbic acid supplementation in diabetes mellitus. Ann Nutr Metab. 1995; 39(4): 217-223.

25. Afkhami-Ardekani M, Shojaoddiny-Ardekani A. Effect of vitamin $C$ onblood glucose, serum lipids \& serum insulin in type 2 diabetes patients. Indian $\mathrm{J}$ Med Res. 2007; 126(5): 471-474.

26. Abdollahzad H, Eghtesadi S, Nourmohammadi I, Khadem-Ansari M, Nejad-Gashti H, Esmaillzadeh A. Effect of vitamin $C$ supplementation on oxidative stress and lipid profiles in hemodialysis patients. Int $\mathrm{J}$ Vitam Nutr Res. 2009; 79(5-6): 281-7. doi: 10.1024/03009831.79.56.281.
27. Tofler GH, Stec JJ, Stubbe I, Beadle J, Feng D, Lipinska I, et al. The effect of vitamin C supplementation on coagulability and lipid levels in healthy male subjects. Thromb Res. 2000; 100(1): 35-41.

28. Block G, Jensen CD, Dalvi TB, Norkus EP, Hudes $\mathrm{M}$, Crawford $\mathrm{PB}$, et al. Vitamin $C$ treatment reduces elevated C-reactive protein. Free Radic Biol Med. 2009; 46(1): 70-7. doi: 10.1016/j.freeradbiomed.2008.09.030.

29. Tousoulis D, Antoniades C, Vasiliadou C, Kourtellaris P, Koniari K, Marinou K, et al. Effects of atrovastatin and vitamin $C$ on forearm hyperaemic blood flow. asymmentrical dimethylarginine levels and the inflammatory process in patients with type 2 diabetes mellitus. Heart. 2007; 93(2): 244-246.

30. Paolisso G, Damore A, Giugliano D, Ceriello A, Varriccho M, Onofrio F. Pharmacologic dose of vitamin E improve insulin action in healthy subjects and noninsulin-dependent diabetic patients. Am J clin Nutr1. 993; 57(5): 650-656.

31. Wu JH, Ward NC, Indrawan AP, Almeida CA, Hodgson JM, Proudfoot JM, et al. Effects of alphatocopherol and mixed tocopherol supplementation on markers of oxidative stress and inflammation in type 2 diabetes. Clin Chem 2007; 53(3): 511-519.

32. Jialal I, Devaraj S, Venugopal SK. Oxidative stress, inflammation, and diabetic vasculopathies: the role of alpha tocopherol therapy. Free Radic Res. 2002; 36(12): 1331-1336.

33. Upritchard JE, Sutherland WH, Mann JI. Effect of supplementation with tomato juice, vitamin $E$, and vitamin $C$ on $L D L$ oxidation and products of inflammatory activity in type 2 diabetes. Diabetes Care. 2000; 23(6):733-738.

34. Devaraj S, Jialal I. Alpha tocopherol supplementation decreases serum $C$-reactive protein and monocyte interleukin-6 levels in normal volunteers and type 2 diabetic patients. Free Radic Biol Med. 2000; 29(8): 790-792.

35. Gomez-Perez FJ, Valles-Sanchez VE, LopezAlvarenga JC, Choza-Romero R, Ibarra Pascuali JJ, Gonzalez Orellana R, et al. Vitamin E modifies neither fructosamine nor HbAlc levels in poorly controlled diabetes. Rev Invest Clin. 1996; 48(6): 421-424.

36. Khabaz M, Rashidi M, Kaseb F, Afkhami-Ardekani M. Effect of Vitamin E on Blood Glucose, Lipid Profile and Blood Pressure in Type 2 Diabetic Patients. IJDO. 2009; 1(1): 11-15

37. McRae MP. Vitamin C supplementation lowers serum low-density lipoprotein cholesterol and triglycerides: a meta-analysis of 13 randomized controlled trials. J Chiropr Med. 2008; 7(2):48-58.

38. Shidfar F, Keshavarz A, Jallali M, Miri R, Eshraghian M. Comparison of the effects of simultaneous administration of vitamin $C$ and omega-3 fatty acids on lipoproteinns, apo A-I, apo B, and malondialdehyde in hyperlipidemic patients. Int J Vitamin Nutr Res. 2003; 73(3): 163-170.

39. Paolisso G,Damore A, Balbi V, Volpe C, Golzerano $\mathrm{D}$, Giugliano D, et al. Plasma vitamin C affects glucose homeostasis in healthy subjects and in non-insulindependent diabetics. Am J Physiol. 1994; 266(2Pt 1): E261-268. 